\title{
Advances in dosimetry and biological predictors of radiation-induced esophagitis
}

This article was published in the following Dove Press journal:

OncoTargets and Therapy

28 January 2016

Number of times this article has been viewed

\section{Yang Yu' \\ Hui Guan' \\ Yuanli Dong' \\ Ligang Xing ${ }^{2}$ \\ Xiaolin $\mathrm{Li}^{2}$}

'School of Medicine and Life Sciences, Shandong Academy of Medical Sciences, University of Jinan, Jinan, ${ }^{2}$ Department of Radiation Oncology, Shandong Cancer Hospital, Jinan, Shandong Province, People's Republic of China
Correspondence: Ligang Xing

Department of Radiation Oncology, Shandong Cancer Hospital, No 440 Jiyan Road, Huaiyin District, Jinan, Shandong 250I I7, People's Republic of China

Tel +8653167626819

Fax +8653167626819

Email xingligang_gmrkj@I26.com
Objective: To summarize the research progress about the dosimetry and biological predictors of radiation-induced esophagitis.

Methods: We performed a systematic literature review addressing radiation esophagitis in the treatment of lung cancer published between January 2009 and May 2015 in the PubMed full-text database index systems.

Results: Twenty-eight eligible documents were included in the final analysis. Many clinical factors were related to the risk of radiation esophagitis, such as elder patients, concurrent chemoradiotherapy, and the intense radiotherapy regimen (hyperfractionated radiotherapy or stereotactic body radiotherapy). The parameters including $\mathrm{D}_{\text {max }}, \mathrm{D}_{\text {mean }}, \mathrm{V}_{20}, \mathrm{~V}_{30}, \mathrm{~V}_{50}$, and $\mathrm{V}_{55}$ may be valuable in predicting the occurrence of radiation esophagitis in patients receiving concurrent chemoradiotherapy. Genetic variants in inflammation-related genes are also associated with radiation-induced toxicity.

Conclusion: Dosimetry and biological factors of radiation-induced esophagitis provide clinical information to decrease its occurrence and grade during radiotherapy. More prospective studies are warranted to confirm their prediction efficacy.

Keywords: lung cancer, esophagitis, radiation injuries, predictors

\section{Introduction}

Increasing use of radiotherapy or concurrent chemoradiotherapy (CCRT) for thoracic cancer (lung, esophageal, or breast cancer) inevitably leads to radiation esophagitis (RE), which emerged as responses to esophageal mucosa irradiation. ${ }^{1}$ During radiotherapy, the esophageal mucosa within the radiation field can incur congestion, edema, or erosion, which are associated with the clinical symptoms including dysphagia, odynophagia, and substernal pain, and even late esophageal stricture, stenosis, and tracheoesophageal fistula. ${ }^{2}$ These adverse side effects are dose-limiting factors that impair the treatment outcome and patient's quality of life.

Several scoring systems for clinical RE have been developed and reported in the medical literature. The studies cited in the present report mostly used the Radiation Therapy Oncology Group (RTOG) scoring system. Some studies used the Common Terminology Criteria for Adverse Events or the National Cancer Institute Common Toxicity Criteria scale. In general, grade 1 toxicity does not affect patients' daily life too much without the need of medical intervention. Grade 2 or higher grade toxicities were recognized as clinically significant, which means medicine is indispensable. ${ }^{3}$ More importantly, a number of dosimetric parameters and biological factors have shown to be correlated with RE, mainly for lung cancer patients.

Prevention and treatment of RE is the key to improve the efficacy of radiotherapy for the thoracic cancer. The purpose of our study was to summarize published dosimetric 
parameters and biological predictors for RE toxicity in recent 5 years for potential clinical use and provide recommendations for future research in the field.

\section{Methods}

RE-related clinical studies were incorporated, which analyzed the relationship between RE and parameters regardless of single parameter or not. In addition, dosimetric parameters predicting RE were constrained to the research for lung cancer radiotherapy without limitation of histology type or clinical stage. No standard chemotherapy regimen was required.

Using radiation-induced esophagitis, radiation-induced esophageal injury as terms, the related lung cancer literature published between January 2009 and May 2015 in the PubMed full-text database index systems was searched. Inclusion criteria were: 1) the characteristics of clinical and radiation dose on radiation-induced esophagitis; 2) the research progress on influencing factors of radiation-induced esophagitis; 3) the research status on biological factors of radiation-induced esophagitis. The reports about the treatment of RE or studies in abstract form were excluded.

\section{Results}

Using the mentioned search strategy, 28 studies were identified. Of these studies, 21 assessed dosimetric parameters of RE (Table 1), three reported biological predictors, while four studies assessed other factors. The relationship between dose-volume histogram parameters cutoff points and RE risk is summarized in Table 2. Most studies focused on acute RE, while only two studies assessed both acute and chronic RE. Two studies assessed any grade of RE, five studies assessed grade 2 or greater RE, and four studies assessed grade 3 or greater RE as the clinically important toxicity, respectively. Nineteen studies graded RE using RTOG criteria, while one study used the common toxicity criteria ${ }^{4}$ and another used the common terminology criteria. ${ }^{5}$ We summarized the results from five aspects as below.

\section{Effect of radiotherapy fraction}

The incidence and extent of esophagitis are correlated with radiotherapy fraction. Higher acute esophagitis (AE) rates are seen with increased RT aggressiveness as hyperfractionation, accelerated, and stereotactic body radiotherapy.

The strong relationship between hyperfractionated CCRT and severe AE was demonstrated in RTOG database analysis for 528 locally advanced non-small-cell lung cancer (LA-NSCLC). ${ }^{6}$ Watkins et $\mathrm{al}^{7}$ analyzed 48 limited-stage small-cell lung cancer (SCLC) patients, who received hyperfractionated-accelerated radiotherapy (median dose 45 Gy, range $42-51 \mathrm{~Gy}$ ), 1.5 Gy bid with concurrent chemotherapy. RTOG grade $3 \mathrm{AE}$ occurred in eleven patients. Mean esophageal dose $\left(\mathrm{D}_{\text {mean }} ; P=0.002\right)$ and relative volume dosimetric area under curve $(P=0.004)$ demonstrated the significant association between grade 3 acute esophagitis. The most strongly associated dosimetric volume was $\mathrm{V}_{15}$ (grade 3 esophagitis rates of $15 \%$ as $\mathrm{V}_{15}<60 \%$ vs $64 \%$ as $\mathrm{V}_{15}>60 \%$ ). Grant et $\mathrm{al}^{8}$ also reported 130 limited-stage SCLC patients treated with the hyperfractionated-accelerated radiotherapy protocol, 25 patients developed severe acute esophagitis. Eight patients $(6 \%, 128$ eligible) experienced esophageal stricture, with six cases in 23 patients who experienced prior grade 3 acute esophagitis (26\%) and another two cases in 105 patients with acute esophagitis $\leq$ grade 2 (2\%). $\mathrm{D}_{\text {mean }}$ and $\mathrm{V}_{5-40}$ were the significant predictors of acute esophagitis. Patients with $\mathrm{V}_{5} \geq 74 \%$ had higher risk of acute grade 3 esophagitis ( $44.4 \%$ as $V_{5} \geq 74 \%$ vs $12.6 \%$ as $\mathrm{V}_{5}<74 \%$ ). $\mathrm{V}_{45}$ was the only significant dosimetric predictor for esophageal stricture (esophageal stricture rates $1.3 \%$ as $\mathrm{V}_{45}<37.5 \%$ vs $13.7 \%$ as $\mathrm{V}_{45} \geq 37.5 \%, P=0.0497$ ). Zehentmayr et $\mathrm{al}^{9}$ investigated dosimetric predictors for $\geq$ grade $2 \mathrm{RE}$ in 66 patients with LA-NSCLC treated with accelerated radiotherapy (1.8 Gy bid). Twenty-three patients (35\%) experienced $\geq$ grade 2 RE. On multivariate analysis, $\mathrm{V}_{38}>34 \%(P=0.007)$ was the most significant predictor for $\geq$ grade $2 \mathrm{RE}$. Mauguen et $\mathrm{al}^{10}$ found hyperfractionated or accelerated radiotherapy increased acute esophagitis rates compared with conventional fractionation radiotherapy for NSCLC (19\% vs 9\%) and SCLC (25\% vs $12 \%)$. However, some studies considered that hyperfractionated or accelerated radiotherapy did not increase the incidence of RE. Manapov et $\mathrm{al}^{11}$ reported that absolute esophageal volume included in the $95 \%$ isodose ( $>42.8 \mathrm{~Gy}$ ) was the only significant variable $(P=0.03)$ predicting severe acute esophagitis ( $>$ grade 2 ). Bar-Ad et al ${ }^{12}$ reported that dose per fraction of 1.8 Gy had a lower risk of $\geq$ grade 2 acute esophagitis as compared with dose per fraction of 2 Gy $(P=0.011)$.

Due to the difference between conventional fraction irradiation and hypofractionated therapy including stereotactic body radiotherapy (SBRT), dosimetric constraints in conventional fraction irradiation could not be applied in hypofractionated setting. SBRT plays more and more important role in treating cancer from central lung zone. Therefore, it is imperative to investigate esophageal complications from SBRT. A retrospective analysis assessed 


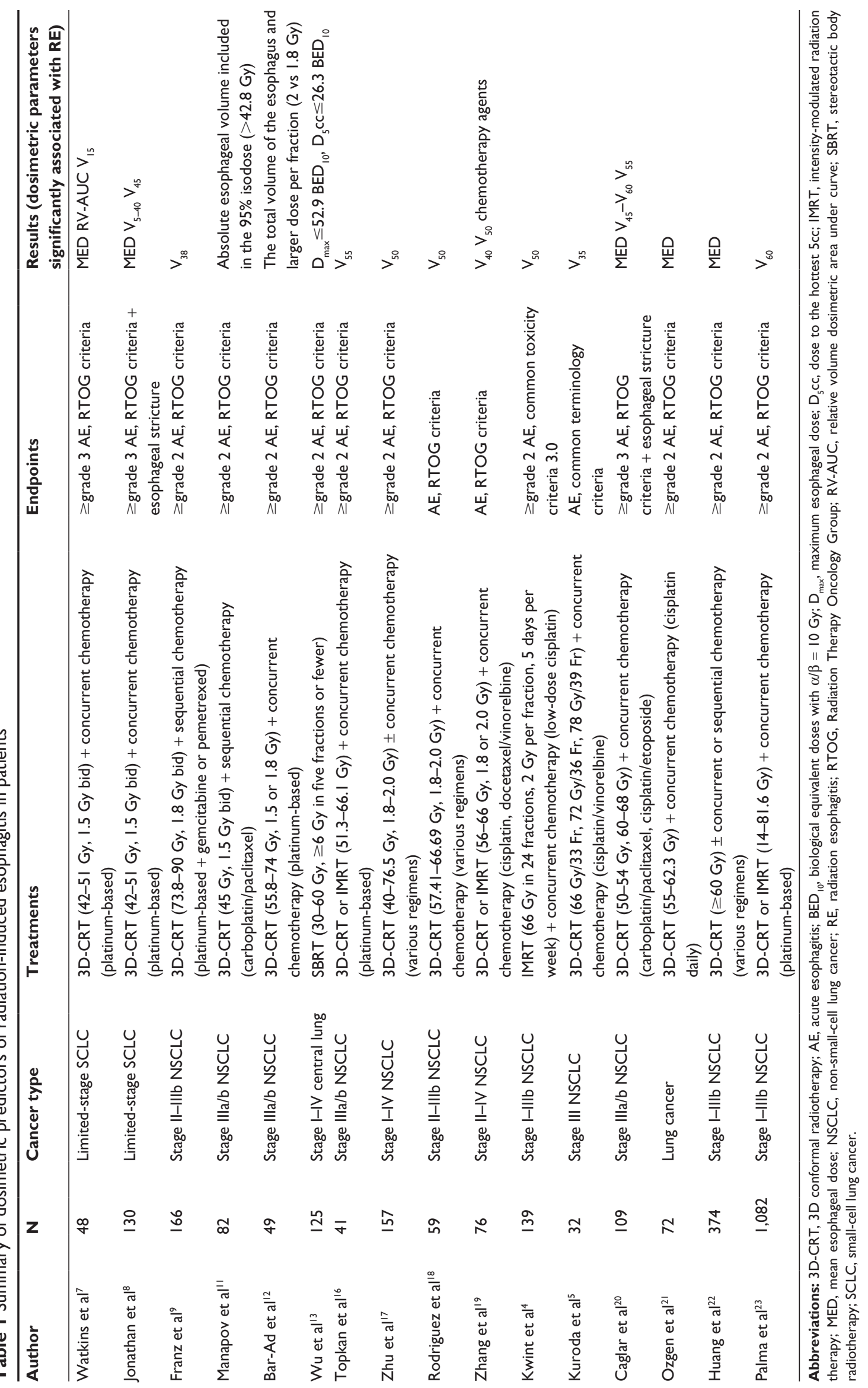


Table 2 Relationship between DVH cutoff points and clinically significant acute esophagitis risk in the literature

\begin{tabular}{|c|c|c|}
\hline Author & Outcome & DVH-acute esophagitis relationships \\
\hline Watkins et al ${ }^{7}$ & $\geq$ grade 3 & $\begin{array}{l}\text { If } V_{15 G y}<60 \% \text { then } \geq \text { grade } 3 \mathrm{AE} \text { risk }=15 \% \\
\text { If } \mathrm{V}_{15 \mathrm{~Gy}} \geq 60 \% \text { then } \geq \text { grade } 3 \mathrm{AE} \text { risk }=64 \%\end{array}$ \\
\hline Jonathan et $\mathrm{al}^{8}$ & $\begin{array}{l}\geq \text { grade } 3 \\
\text { esophageal stricture }\end{array}$ & $\begin{array}{l}\text { If } \mathrm{V}_{5 \mathrm{~Gy}}<74 \% \text { then } \geq \text { grade } 3 \mathrm{AE} \text { risk }=12.6 \% \\
\text { If } \mathrm{V}_{5 \mathrm{~Gy}} \geq 74 \% \text { then } \geq \text { grade } 3 \mathrm{AE} \text { risk }=44.4 \% \\
\text { If } \mathrm{V}_{45 \mathrm{~Gy}}<37.5 \% \text { then esophageal stricture rate }=1.3 \% \\
\text { If } \mathrm{V}_{45 \mathrm{~Gy}} \geq 37.5 \% \text { then esophageal stricture rate }=13.7 \%\end{array}$ \\
\hline Franz et al ${ }^{9}$ & $\geq$ grade 2 & If $\mathrm{V}_{38 \mathrm{~Gy}}<34 \%$ then $\geq$ grade $2 \mathrm{AE}$ risk $\leq 30 \%$ \\
\hline Topkan et al ${ }^{16}$ & $\geq$ grade 2 & $\begin{array}{l}\text { If } \mathrm{V}_{55 \mathrm{~Gy}}<35 \% \text { then } \geq \text { grade } 2 \text { or } 3 \mathrm{AE} \text { risk }=31 \% \\
\text { If } \mathrm{V}_{55 \mathrm{~Gy}} \geq 35 \% \text { then } \geq \text { grade } 2 \text { or } 3 \mathrm{AE} \text { risk }=76 \%\end{array}$ \\
\hline Rodriguez et al ${ }^{18}$ & $\geq$ grade 2 & $\begin{array}{l}\text { If } \mathrm{V}_{50 \mathrm{~Gy}}<30 \% \text { then } \geq \text { grade I } \mathrm{AE} \text { risk }=47.3 \% \\
\text { If } \mathrm{V}_{50 \mathrm{~Gy}} \geq 30 \% \text { then } \geq \text { grade I } \mathrm{AE} \text { risk }=73.3 \%\end{array}$ \\
\hline Zhang et al ${ }^{19}$ & $\begin{array}{l}\geq \text { grade } 2 \\
\geq \text { grade } 3\end{array}$ & $\begin{array}{l}\text { If } \mathrm{V}_{40 \mathrm{~Gy}}<23 \% \text { and concurrent chemotherapy then } \geq \text { grade } 2 \mathrm{AE} \text { risk }=33.3 \% \\
\text { If } \mathrm{V}_{40 \mathrm{GY}} \geq 23 \% \text { and concurrent chemotherapy then } \geq \text { grade } 2 \mathrm{AE} \text { risk }=89.1 \% \\
\text { If } \mathrm{V}_{50 \mathrm{~Gy}}<26.5 \% \text { and concurrent chemotherapy then } \geq \text { grade } 3 \mathrm{AE} \text { risk }=6.7 \% \\
\text { If } \mathrm{V}_{50 \mathrm{~Gy}} \geq 26.5 \% \text { and concurrent chemotherapy then } \geq \text { grade } 3 \mathrm{AE} \text { risk }=38.7 \%\end{array}$ \\
\hline Kuroda et al ${ }^{5}$ & $\geq$ grade 2 & $\begin{array}{l}\text { If } \mathrm{V}_{35 \mathrm{~Gy}}<20 \% \text { then } \geq \text { grade } 2 \mathrm{AE} \text { risk }=35.7 \% \\
\text { If } \mathrm{V}_{35 \mathrm{~Gy}} \geq 20 \% \text { then } \geq \text { grade } 2 \mathrm{AE} \text { risk }=88.9 \%\end{array}$ \\
\hline Ozgen et $\mathrm{al}^{21}$ & $\geq$ grade 2 & $\begin{array}{l}\text { If } M E D<28 \text { Gy then } \geq \text { grade } 2 \mathrm{AE} \text { risk }=0 \% \\
\text { If } M E D \geq 28 \text { Gy then } \geq \text { grade } 2 \mathrm{AE} \text { risk }=60.7 \%\end{array}$ \\
\hline
\end{tabular}

Abbreviations: AE, acute esophagitis; DVH, dose-volume histogram; MED, mean esophageal dose in Gy.

esophageal toxicity in 125 SBRT patients, using biological equivalent doses with $\alpha / \beta=10$ Gy $\left(\mathrm{BED}_{10}\right) \cdot{ }^{13}$ Dose to the hottest $5 \mathrm{cc}\left(\mathrm{D}_{5} \mathrm{cc}\right)$ and maximum dose of the esophagus $\left(\mathrm{D}_{\text {max }}\right)$ were the best predictors of $\geq$ grade 2 acute RE. To keep the acute RE rate $<20 \%$, it was suggested to keep $\mathrm{D}_{\max } \leq 52.9$ Gy and $\mathrm{D}_{5} \mathrm{cc} \leq 26.3 \mathrm{~Gy}$. In addition, $\mathrm{D}_{5} \mathrm{cc}$ should be kept $<16.8,18.1$, and $19.0 \mathrm{~Gy}, \mathrm{D}_{\max }$ should be kept $<27.6,30.2$, and $32.2 \mathrm{~Gy}$, for 3, 4, and 5 fractions of SBRT, respectively.

\section{Dose-volumetric parameters}

CCRT was widely administrated in treating inoperable LANSCLC and improved local control and overall survival compared with radiotherapy alone. ${ }^{14}$ However, the acute toxicity also increased ${ }^{15}$ (RTOG 9410 trial investigating three different regimens reported a $45 \%$ of grade 3 acute esophagitis in the CCRT arm). Physical factors are important basis for predicting acute esophagitis and formulating radiotherapy planning in 3D conformal radiotherapy or intensity-modulated radiation therapy. The parameters include the absolute volume, mean dose $\left(\mathrm{D}_{\text {mean }}\right)$, or percentage of a reference volume $\left(\mathrm{V}_{\text {dose }}\right)$, or maximum dose $\left(\mathrm{D}_{\max }\right)$ of the esophagus. Topkan et al ${ }^{16}$ found $\mathrm{V}_{55}$ was the only dosimetric predictor for RTOG grade 2 or greater acute esophagitis on multivariate analysis: $\mathrm{V}_{55}<35 \%$ had a $31 \%$ risk of $\mathrm{RE}$ grade 2 or 3 , and the risk increased to $76 \%$ as $\mathrm{V}_{55} \geq 35 \%$ $(P=0.01)$. Zhu et al ${ }^{17}$ reported that grade 2 or $3 \mathrm{RE}$ occurred in $24 \%$ in the radiotherapy-alone group and $52 \%$ in the CCRT group. They found that $\mathrm{V}_{50}$ was the only significant factor in multivariate analysis. Rodriguez et al ${ }^{18}$ revealed that $\mathrm{V}_{50}$ was the most statistically significant factor (grade $\geq 1 \mathrm{RE}$ risk: $47.3 \%$ as $\mathrm{V}_{50}<30 \%, 73.3 \%$ as $\mathrm{V}_{50} \geq 30 \%$ ). $\mathrm{V}_{50}$ was also the significant predictor for $\mathrm{RE} \geq$ grade 3 in the study by Kwint et al. ${ }^{4}$ Zhang et $\mathrm{al}^{19}$ demonstrated that, in CCRT, $\mathrm{V}_{40}$ was the significant factor associated with grade $\geq 2 \mathrm{RE}$ (33.3\% as $\mathrm{V}_{40}<23 \%$ vs $89.1 \%$ as $\mathrm{V}_{40} \geq 23 \%$ ) and $\mathrm{V}_{50}$ was significantly correlated with grade $3 \mathrm{RE}\left(6.7 \%\right.$ as $\mathrm{V}_{50}<26.5 \%$ vs $38.7 \%$ as $\mathrm{V}_{50} \geq 26.5 \%$ ). Kuroda et $\mathrm{al}^{5}$ revealed that $\mathrm{V}_{35}$ was the only dosimetric predictor for grade $\geq 2 \mathrm{RE}$ on multivariate analysis. Caglar et $\mathrm{al}^{20}$ found that $\mathrm{D}_{\text {mean }}$ and $\mathrm{V}_{45}-\mathrm{V}_{60}$ were significantly associated with the risk of grade $\geq 3 \mathrm{RE}$. $V_{55}$ and $V_{60}$ for the entire esophagus (Esoph) and esophagus infield $\left(E\left(\mathrm{soph}_{\mathrm{in}}\right)\right.$ significantly correlated with development of esophageal stricture. $\mathrm{V}_{55}$ Esoph $_{\text {in }}$ to $50 \%$ was the best cutoff point for acute esophagitis. Both Ozgen et $\mathrm{al}^{21}$ and Huang et $\mathrm{a}^{22}$ reported that $\mathrm{D}_{\text {mean }}$ was significantly correlated with grade $\geq 2$ RE. Palma et $\mathrm{al}^{23}$ reported that $\mathrm{V}_{60}$ was the best predictor of RE, while $\mathrm{V}_{60}>17 \%$ conferred the higher risk of grade $\geq 3$ RE.

\section{Multiple parameters analysis}

Given the heterogeneity among studies, and the limitation of single predicting factor, some research focused on multiple parameter analysis about the predicting factors for RE. Gu et $\mathrm{al}^{24}$ found that radiation sensitization, length of irradiated esophagus, average dose of irradiated esophagus, 
and $\mathrm{V}_{50}$ were independent factors for the occurrence of RE. Zhang et al revealed that lymph nodes stage, pretreatment weight loss $\geq 5 \%$, concurrent chemotherapy, and the use of late-course hyperfractionated radiotherapy were significantly associated with grade 2 and 3 RE..$^{25}$ Dose-volume parameters correlating $\mathrm{RE}$ included $\mathrm{D}_{\text {mean }}, \mathrm{D}_{\text {max }}$, and relative volume $\left(\mathrm{rV}_{15-60}\right)$.

Multiple volumetric metrics were reported as the absolute volume or area, relative volume or area, and circumferential measures, which made it difficult for dosimetric recommendations. However, by comparison of reports with similar radiotherapy protocol, some consistent conclusion could be drawn. Among the ten studies using CCRT, nine studies assessed one or all of following parameters: maximum esophageal dose, mean esophageal dose, median esophageal dose, or total esophageal dose. All ten studies assessed $\mathrm{V}_{\text {dose }}$. Three studies assessed irradiated esophagus length and volume, three studies assessed the normal tissue complication probability, and one study assessed relative and absolute volume of the esophagus in the radiation field. All these parameters significantly correlated with RE in the original studies. Of these parameters, $\operatorname{six}\left(\mathrm{D}_{\text {max }}, \mathrm{D}_{\text {mean }}, \mathrm{V}_{20}\right.$, $\mathrm{V}_{30}, \mathrm{~V}_{50}$, and $\mathrm{V}_{55}$ ) were evaluated in five or more studies and significantly associated with RE (Table 3). By further analysis, it was found that $\mathrm{D}_{\text {max }}, \mathrm{D}_{\text {mean }}, \mathrm{V}_{20}, \mathrm{~V}_{30}, \mathrm{~V}_{50}$, and $\mathrm{V}_{55}$ were correlated with acute $\mathrm{RE}$, and $\mathrm{D}_{\text {mean }}$ and $\mathrm{V}_{55}$ were correlated with both acute RE and late esophageal stricture.

Table 3 Number and percentage of studies demonstrating a significant relationship between dosimetric parameters and RE

\begin{tabular}{lll}
\hline Dosimetric parameter & $\begin{array}{l}\text { Number } \\
\text { of studies }\end{array}$ & $\begin{array}{l}\text { Significant results } \\
\text { with acute RE (\%) }\end{array}$ \\
\hline$D_{\text {total }}$ esophagus & 2 & $1 / 2(50)$ \\
$D_{\text {mean }}$ & 9 & $8 / 9(89)$ \\
$D_{\text {max }}$ & 7 & $6 / 7(86)$ \\
Irradiated esophagus length & 3 & $3 / 3(100)$ \\
Irradiated esophagus volume & 3 & $3 / 3(100)$ \\
$V_{5}$ & 3 & $2 / 3(67)$ \\
$V_{10}$ & 4 & $2 / 4(50)$ \\
$V_{15}$ & 5 & $3 / 5(60)$ \\
$V_{20}$ & 9 & $7 / 9(78)$ \\
$V_{25}$ & 5 & $3 / 5(60)$ \\
$V_{30}$ & 9 & $7 / 9(78)$ \\
$V_{35}$ & 7 & $4 / 7(57)$ \\
$V_{40}$ & 9 & $6 / 9(67)$ \\
$V_{45}$ & 8 & $5 / 8(63)$ \\
$V_{50}$ & 10 & $7 / 10(70)$ \\
$V_{55}$ & 8 & $6 / 8(75)$ \\
$V_{60}$ & 9 & $6 / 9(67)$ \\
$V_{65}$ & 2 & $0 / 2(0)$ \\
\hline
\end{tabular}

Abbreviations: $D_{\text {mean }}$, mean esophageal dose in $G y ; D_{\text {max }}$, maximum esophageal dose; RE, radiation esophagitis.

\section{Biological predictors of radiation-induced esophagitis}

Biological factors, such as genetic variation play an important role in radiation-induced normal tissue damage. Discriminating patients with high risks of treatment-related toxicities based on biological factors could optimize treatment decision and lead to personalized radiotherapy.

Transforming growth factor-beta 1 (TGF- $\beta 1$ ) elevated dramatically in response to radiation exposure. ${ }^{26}$ Common variants located in TGF- $\beta 1$ have been found to have connection with late normal tissue complications after irradiation. Recently, an increasing number of studies related variants in TGF- $\beta 1$ to RE. Hildebrandt et $\mathrm{al}^{27}$ found that nine TGF- $\beta 1$ single nucleotide polymorphisms (SNPs) were associated with a 1.5- to 4-fold increase of esophagitis risk, including three PTGS2 (COX2) variants: rs20417, rs5275, and rs689470. The cumulative effect of these SNPs on risk was dose-dependent, as evidenced by a significantly increased risk of either toxicity with an increasing number of genotypes. Another study showed that the CG/GG genotype of HSPB1 rs2868371 was associated with significantly lower risk of grade $\geq 3 \mathrm{RE}$ than the $\mathrm{CC}$ genotype. ${ }^{28}$ Yuan et al ${ }^{29}$ also found TGF- $\beta 1$ genotype was associated with RE in NSCLC patients. Patients with TGF- $\beta 1$ 509CC had greater grade RE than T allele carriers. Therefore, TGF- $\beta 1$ SNP could be used as a predictive biomarker for the studied endpoint and might be used for guiding therapy intensity or interventions for toxicity in NSCLC patients.

\section{Other factors}

Recent studies have investigated the correlation between RE with imaging and hematology parameters. Court et $\mathrm{al}^{30}$ found that CT imaging could be used to quantify radiation-induced injury to the esophagus. Esophagus expansion on CT images has potential as an objective of toxicity. Yuan et $\mathrm{al}^{31}$ and Nijkamp et $\mathrm{al}^{32}$ found that 2-[fluorine-18]fluoro-2-deoxy-Dglucose uptake in esophagus increased during radiotherapy and this increase reflected the degree of RE. Tang et $\mathrm{al}^{33}$ used the physiologic acute phase response (APR) score as risk factors to predict RE: platelet counts $\geq 377 \times 10^{3} / \mu \mathrm{L}$, hemoglobin $<12.9 \times 10^{3} \mathrm{~d} / \mathrm{L}$. Based on these two risk factors, an APR score was defined as 0 (no risk factors), 1 (either risk factor), or 2 (both risk factors). More esophagitis occurred in patients with a grade 2 APR score $(P<0.05)$.

\section{Conclusion and prospect}

Present review summarized the physical and biological predictors of RE in recent reports, mainly for NSCLC. Currently, 
there was no clear threshold of volumetric parameters in predicting $\mathrm{RE}$, because a wide range of $\mathrm{V}_{\text {dose }}$ parameters significantly correlated with severe acute esophagitis. Future studies should not only investigate the correlation, but also address the cutoff value.

These findings provide useful information for RE prevention, especially as dosimetry parameters for intensity-modulated radiation therapy plans. The research of biomarkers of normal tissue radiosensitivity provided new pathway for the prediction and treatment of RE. Future analyses of esophagitis should employ multivariate factors models. Further multicenter study with a larger number of patients is warranted to validate these physical and biological factors in predicting RE.

\section{Acknowledgment}

This study was supported by the grants from the National Science Foundation of China (No 81502667) and Shandong Natural Science Foundation (No ZR2014HP041).

\section{Disclosure}

The authors declare no conflicts of interest in this work.

\section{References}

1. Belderbos J, Heemsbergen W, Hoogeman M, Pengel K, Rossi M, Lebesque J. Acute esophageal toxicity in non-small cell lung cancer patients after high dose conformal radiotherapy. Radiother Oncol. 2005;75(2):157-164.

2. Choy H, LaPorte K, Knill-Selby E, Mohr P, Shyr Y. Esophagitis in combined modality therapy for locally advanced non-small cell lung cancer. Semin Radiat Oncol. 1999;9(2 Supp1 1):S90-S96.

3. Takeda K, Nemoto K, Saito H, Ogawa Y, Takai Y, Yamada S. Predictive factors for acute esophageal toxicity in thoracic radiotherapy. Tohoku $J$ Exp Med. 2006;208(4):299-306.

4. Kwint M, Uyterlinde W, Nijkamp J, et al. Acute esophagus toxicity in lung cancer patients after intensity modulated radiation therapy and concurrent chemotherapy. Int J Radiat Oncol Biol Phys. 2012;84(2):e223-e228.

5. Kuroda Y, Sekine I, Sumi M, et al. Acute radiation esophagitis caused by high-dose involved field radiotherapy with concurrent cisplatin and vinorelbine for stage III non-small cell lung cancer. Technol Cancer Res Treat. 2013;12(4):333-339.

6. Werner-Wasik M, Paulus R, Curran WJ Jr, Byhardt R. Acute esophagitis and late lung toxicity in concurrent chemoradiotherapy trials in patients with locally advanced non-small-cell lung cancer: analysis of the radiation therapy oncology group (RTOG) database. Clin Lung Cancer. 2011;12(4):245-251.

7. Watkins JM, Wahlquist AE, Shirai K, et al. Factors associated with severe acute esophagitis from hyperfractionated radiotherapy with concurrent chemotherapy for limited-stage small-cell lung cancer. Int J Radiat Oncol Biol Phys. 2009;74(4):1108-1113.

8. Grant JD, Shirvani SM, Tang C, et al. Incidence and predictors of severe acute esophagitis and subsequent esophageal stricture in patients treated with accelerated hyperfractionated chemoradiation for limited-stage small cell lung cancer. Pract Radiat Oncol. 2015;5(4):e383-e391.

9. Zehentmayr F, Sohn M, Exeli AK, et al. Normal tissue complication models for clinically relevant acute esophagitis $(>/=$ grade 2$)$ in patients treated with dose differentiated accelerated radiotherapy (DART-bid). Radiat Oncol. 2015;10(1):121.
10. Mauguen A, Le Pechoux C, Saunders MI, et al. Hyperfractionated or accelerated radiotherapy in lung cancer: an individual patient data meta-analysis. J Clin Oncol. 2012;30(22):2788-2797.

11. Manapov F, Sepe S, Niyazi M, Belka C, Friedel G, Budach W. Dosevolumetric parameters and prediction of severe acute esophagitis in patients with locally-advanced non small-cell lung cancer treated with neoadjuvant concurrent hyperfractionated-accelerated chemoradiotherapy. Radiat Oncol. 2013;8:122.

12. Bar-Ad V, Leiby B, Witek M, et al. Treatment-related acute esophagitis for patients with locoregionally advanced non-small cell lung cancer treated with involved-field radiotherapy and concurrent chemotherapy. Am J Clin Oncol. 2014;37(5):433-437.

13. Wu AJ, Williams E, Modh A, et al. Dosimetric predictors of esophageal toxicity after stereotactic body radiotherapy for central lung tumors. Radiother Oncol. 2014;112(2):267-271.

14. Pignon JP, Stewart LA. Randomized trials of radiotherapy alone versus combined chemotherapy and radiotherapy in stages III a and IIIb nonsmall cell lung cancer: a meta-analysis. Cancer. 1996;77(11):2413-2414.

15. Curran WJ Jr, Paulus R, Langer CJ, et al. Sequential vs concurrent chemoradiation for stage III non-small cell lung cancer: randomized phase III trial RTOG 9410. J Natl Cancer Inst. 2011;103(19):1452-1460.

16. Topkan E, Yavuz MN, Onal C, Yavuz AA. Prevention of acute radiationinduced esophagitis with glutamine in non-small cell lung cancer patients treated with radiotherapy: evaluation of clinical and dosimetric parameters. Lung Cancer. 2009;63(3):393-399.

17. Zhu J, Zhang ZC, Li BS, et al. Analysis of acute radiation-induced esophagitis in non-small-cell lung cancer patients using the Lyman NTCP model. Radiother Oncol. 2010;97(3):449-454.

18. Rodriguez N, Algara M, Foro P, et al. Predictors of acute esophagitis in lung cancer patients treated with concurrent three-dimensional conformal radiotherapy and chemotherapy. Int J Radiat Oncol Biol Phys. 2009;73(3):810-817.

19. Zhang Z, Xu J, Zhou T, et al. Risk factors of radiation-induced acute esophagitis in non-small cell lung cancer patients treated with concomitant chemoradiotherapy. Radiat Oncol. 2014;9:54.

20. Caglar HB, Othus M, Allen AM. Esophagus in-field: a new predictor for esophagitis. Radiother Oncol. 2010;97(1):48-53.

21. Ozgen A, Hayran M, Kahraman F. Mean esophageal radiation dose is predictive of the grade of acute esophagitis in lung cancer patients treated with concurrent radiotherapy and chemotherapy. $J$ Radiat Res. 2012;53(6):916-922.

22. Huang EX, Bradley JD, El Naqa I, et al. Modeling the risk of radiationinduced acute esophagitis for combined Washington University and RTOG trial 93-11 lung cancer patients. Int J Radiat Oncol Biol Phys. 2012;82(5):1674-1679.

23. Palma DA, Senan S, Oberije C, et al. Predicting esophagitis after chemoradiation therapy for non-small cell lung cancer: an individual patient data meta-analysis. Int J Radiat Oncol Biol Phys. 2013; 87(4):690-696.

24. Gu T, Hua HX, Fu ZZ, et al. Multi-factor analysis of radiation-induced esophagitis in three-dimensional conformal radiotherapy for non-small cell lung cancer. Zhonghua Zhong Liu Za Zhi. 2011;33(11):868-871. Chinese.

25. Zhang ZC, Xu J, Li BS, et al. Clinical and dosimetric risk factors of acute esophagitis in patients treated with 3-dimensional conformal radiotherapy for non-small-cell lung cancer. Am J Clin Oncol. 2010;33(3): 271-275.

26. Andreassen CN, Alsner J, Overgaard M, Overgaard J. Prediction of normal tissue radiosensitivity from polymorphisms in candidate genes. Radiother Oncol. 2003;69(2):127-135.

27. Hildebrandt MA, Komaki R, Liao Z, et al. Genetic variants in inflammation-related genes are associated with radiation-induced toxicity following treatment for non-small cell lung cancer. PLoS One. 2010;5(8):e12402.

28. Lopez Guerra JL, Wei Q, Yuan X, et al. Functional promoter rs 2868371 variant of HSPB1 associates with radiation-induced esophageal toxicity in patients with non-small-cell lung cancer treated with radio(chemo) therapy. Radiother Oncol. 2011;101(2):271-277. 
29. Yuan ST, Ellingrod VL, Schipper M, et al. Genetic variations in TGFbeta1, tPA, and ACE and radiation-induced thoracic toxicities in patients with non-small-cell lung cancer. J Thorac Oncol. 2013;8(2): 208-213.

30. Court LE, Tucker SL, Gomez D, et al. A technique to use CT images for in vivo detection and quantification of the spatial distribution of radiationinduced esophagitis. J Appl Clin Med Phys. 2013;14(3):4195.

31. Yuan ST, Brown RK, Zhao L, et al. Timing and intensity of changes in FDG uptake with symptomatic esophagitis during radiotherapy or chemo-radiotherapy. Radiat Oncol. 2014;9(1):37.
32. Nijkamp J, Rossi M, Lebesque J, et al. Relating acute esophagitis to radiotherapy dose using FDG-PET in concurrent chemo-radiotherapy for locally advanced non-small cell lung cancer. Radiother Oncol. 2013; 106(1):118-123.

33. Tang C, Liao Z, Zhuang Y, et al. Acute phase response before treatment predicts radiation esophagitis in non-small cell lung cancer. Radiother Oncol. 2014;110(3):493-498.

\section{Publish your work in this journal}

OncoTargets and Therapy is an international, peer-reviewed, open access journal focusing on the pathological basis of all cancers, potential targets for therapy and treatment protocols employed to improve the management of cancer patients. The journal also focuses on the impact of management programs and new therapeutic agents and protocols on

\section{Dovepress}

patient perspectives such as quality of life, adherence and satisfaction. The manuscript management system is completely online and includes a very quick and fair peer-review system, which is all easy to use. Visit http://www.dovepress.com/testimonials.php to read real quotes from published authors.

Submit your manuscript here: http://www.dovepress.com/oncotargets-and-therapy-journal 